\title{
Maize Seedling Establishment, Grain Yield and Crop Water Productivity Response to Seed Priming and Irrigation Management in a Mediterranean Arid Environment
}

\author{
AbdAllah M. El-Sanatawy ${ }^{1}$, Ahmed S. M. El-Kholy ${ }^{1}$, Mohamed M. A. Ali ${ }^{1}$, Mohamed F. Awad ${ }^{2}(\mathbb{D}$ \\ and Elsayed Mansour ${ }^{1, *(1)}$ \\ 1 Agronomy Department, Faculty of Agriculture, Zagazig University, Zagazig 44519, Egypt; \\ elsanatawyabdallah2@gmail.com (A.M.E.); ahmedelkholy@zu.edu.eg (A.S.M.E.); \\ abd_lhamed@yahoo.com (M.M.A.A.) \\ 2 Department of Biology, College of Science, Taif University, P.O. Box 11099, Taif 21944, Saudi Arabia; \\ m.fadl@tu.edu.sa \\ * Correspondence: sayed_mansour_84@yahoo.es
}

check for updates

Citation: El-Sanatawy, A.M.; El-Kholy, A.S.M.; Ali, M.M.A.; Awad, M.F.; Mansour, E. Maize Seedling Establishment, Grain Yield and Crop Water Productivity Response to Seed Priming and Irrigation Management in a Mediterranean Arid Environment. Agronomy 2021, 11, 756.

https://doi.org/10.3390/ agronomy11040756

Received: 18 March 2021

Accepted: 9 April 2021

Published: 13 April 2021

Publisher's Note: MDPI stays neutral with regard to jurisdictional claims in published maps and institutional affiliations.

Copyright: (c) 2021 by the authors. Licensee MDPI, Basel, Switzerland. This article is an open access article distributed under the terms and conditions of the Creative Commons Attribution (CC BY) license (https:// creativecommons.org/licenses/by/ $4.0 /)$.

\begin{abstract}
Water shortage is a major environmental stress that destructively impacts maize production, particularly in arid regions. Therefore, improving irrigation management and increasing productivity per unit of water applied are needed, especially under the rising temperature and precipitation fluctuations induced by climate change. Laboratory and field trials were carried out in the present study, which were aimed at assessing the possibility of promoting maize germination, growth, grain yield and crop water productivity (CWP) using seed priming under different irrigation regimes. Two seed priming treatments, i.e., hydro-priming and hardening versus unprimed seeds, were applied under four irrigation regimes, i.e., 120, 100, 80 and 60\% of estimated crop evapotranspiration (ETc). The obtained results indicated that increasing irrigation water from $100 \%$ up to $120 \%$ ETc did not significantly increase grain yield or contributing traits, while it decreased CWP. Deficit irrigation of 80 and $60 \%$ ETc gradually decreased grain yield and all attributed traits. Seed priming significantly ameliorated seedlings' vigor as indicated by earlier germination, higher germination percentage, longer roots and shoots, and heavier fresh and dry weight than unprimed seeds with the superiority of hardening treatment. Additionally, under field conditions, seed priming significantly increased grain yield, yield contributing traits and CWP compared with unprimed treatment. Interestingly, the results reflect the role of seed priming, particularly hardening, in mitigating negative impacts of drought stress and enhancing maize growth, grain yield and attributed traits as well as CWP under deficit irrigation conditions. This was demonstrated by a significant increase in grain yield and CWP under moderate drought and severe drought conditions compared with unprimed treatment. These results highlight that efficient irrigation management and seed priming can increase maize yield and water productivity in arid environments.
\end{abstract}

Keywords: irrigation regimes; hydro-priming; hardening; seed germinability; seedlings vigor; agronomic traits; principal component analysis; quadratic diminishing response

\section{Introduction}

Water resources are limited in arid and semi-arid regions, with more frequent drought events in a changing climate [1,2]. These circumstances necessitate appropriate management and optimization of the use of available water resources, as do the growing human population and increasing food demand [3-6]. The agricultural practices can contribute to saving available water resources by supplying precise crop water requirements without wasting water by excess irrigation $[7,8]$. Crop water requirements can be identified by crop evapotranspiration (ETc), which is a vital parameter in water management and agricultural production $[9,10]$. ETc is calculated indirectly using reference crop evapotranspiration 
(ETo) and crop coefficients $(K c)$ as suggested by [11]. ETo is calculated based on weather variables of air temperature, solar radiation, wind speed and vapor pressure following FAO Penman-Monteith method [11-13]. The general trend of temperature is expected to increase with more frequent drought events and variations in solar radiation and wind speed as a result of climatic variability. These fluctuations will negatively influence the hydrological system and water resources through ETo $[14,15]$. Accordingly, it is important to estimate ETo periodically to schedule adequate irrigation requirements and avoid wasting water by excess irrigation.

Maize (Zea mays L.) is one of the main cereal crops in the world, ranking first in respect of total production and second regarding cultivated acreage after wheat [16]. Its total area cultivated in 2019 was 197.2 million hectares, which produced 1148.5 million tonnes [16]. Maize is in increasing demand because it is considered a major source of food, feed and energy. It is mostly used in the feeding of livestock and poultry as well as in industrial products, including starch and fuel ethanol production $[17,18]$. Notwithstanding, it is a crop sensitive to water stress, which adversely affects its growth and productivity $[19,20]$. Water deficit causes destructive impacts on maize plants by reducing photosynthetic pigments, relative water content, stomatal conductance, transpiration rate and photosynthetic efficiency, which negatively reflect on grain yield and attributed traits [21-23]. Consequently, it is important to apply efficient irrigation management to increase maize yield and water productivity, in particular in arid environments. Furthermore, it is essential to investigate efficient approaches to alleviate the deleterious impacts of water deficit on field crops, which are projected to increase due to climate change, particularly in dry regions $[5,6,22]$.

Seed germination and seedling vigor are decisive factors for the successful growth of field crops [24,25]. Rapid germination, uniform emergence, vigorous seedlings and strong early growth reflect high potentials for crop stand establishment and a successful cropping system, in particular under water scarcity conditions [25,26]. Enhancing stand establishment is known by researchers and farmers as an essential requirement for high productivity. Seed priming is a supplementary low-cost and eco-friendly pre-sowing approach that can improve germination rate and seedlings' vigor, which are reflected in enhanced crop growth and productivity [27-30]. It ameliorates germination and seedling establishment through enhancing metabolic activities, enzyme activation, the antioxidant system and embryo enlargement [31-34]. During priming, $\alpha$ - and $\beta$-amylase are activated and stored reserves (proteins, carbohydrates, fat and lipids) are converted into compounds necessary for germination and seedling growth $[35,36]$. Furthermore, seed priming elevates respiratory activity and adenosine triphosphate (ATP) production, which promote metabolic activity and hastens the germination process $[37,38]$. Likewise, seed priming increases catalase, peroxidase and superoxide dismutase activities as well as reinforces stabilizing membrane integrity and cellular defense responses which stimulates germination and uniform stand establishment especially under stressful conditions $[39,40]$.

Hydro-priming is one of the priming approaches that relies on soaking seeds overnight followed by drying to original moisture content [41,42]. It is an applicable, economical and efficacious strategy which allows seeds to absorb enough water to initiate the metabolic process and, thereby, improves seed germination and seedling vigor. Subsequently, this technique boosts seed germination, seedling establishment, plant growth and productivity under optimal or deficit irrigation conditions [24,38,42]. Seed hardening is another efficient approach and works by alternating seed hydration and dehydration; a process which is repeated once or twice. It induces termination of leaching the essential components in seeds and hardened seed coat, causing improvement of germinability. Accordingly, it elevates seed germination and seedling vigor as well as stimulates plant growth and productivity, in particular under water shortage [43,44]. Despite several published literature on seed priming, gaps remain in knowledge on how maize growth, yield and water productivity are responding to seed priming under different irrigation regimes in arid environments as study region. 
The objectives of this study were (i) to investigate the effect of excessive or deficit irrigation conditions on grain yield, yield contributing traits and crop water productivity (CWP), (ii) to determine the impacts of seed priming on maize stand establishment, grain yield, yield contributing traits and CWP under various irrigation levels in an arid environment, and (iii) to produce an irrigation management recommendation that maximizes CWP without unacceptable yield loss in arid environments.

\section{Materials and Methods}

\subsection{Laboratory Trial}

\subsubsection{Seed Priming Treatments}

A group of 450 healthy maize seeds (single-cross hybrid Giza-162) were surface sterilized with $0.1 \% \mathrm{HgCl}_{2}$ solution for $90 \mathrm{~s}$ and then washed with distilled water three times. The sterilized seeds were divided into three equal groups: (i) the first group was used as a control without treatment (unprimed), (ii) the second group was a hydro-priming treatment in which seeds were soaked in distilled water for $12 \mathrm{~h}$ and then re-dried to their original weight with forced air at room temperature, and (iii) the third group was used as hardening treatment by exposing seeds to two cycles, i.e., first cycle seeds were soaked in distilled water for $12 \mathrm{~h}$ and then re-dried back to original weight and the second cycle seeds were soaked for $6 \mathrm{~h}$ and then re-dried to the original weight. Priming treatments were conducted separately at $20^{\circ} \mathrm{C}$ in the dark.

\subsubsection{Laboratory Measurements}

Seed germination and seedling vigor were investigated in the laboratory using completely randomized design. Seeds of the three treatments were germinated at $25 \pm 1{ }^{\circ} \mathrm{C}$ in a dark growth chamber in plastic trays with moist blotting paper. Seed germinability and seedling vigor tests were determined using four groups of 25 seeds (100 seeds) for each treatment as four replicates. Seeds were considered as germinated when coleoptile and radicle lengths had grown to about $2 \mathrm{~mm}$. Germinated seeds were counted daily and terminated when no further germination occurred (after 11 days). The rest of the seeds were checked daily to ensure that the germination did not occur. The following germination parameters were determined:

Germination percentage $(\mathrm{GP})=($ Number of germinated seeds $) /($ Number of tested seeds $) \times 100$

Germination index $(\mathrm{GI})=($ Number of germinated seeds $) /($ days of the first count $)+\cdots+($ Number of germinated seeds)/(days of the last count)

Energy of germination $(\mathrm{EG})=($ Germination percentage on determine day (fifth day) $) /($ Total number of tested seeds) $\times 100$

Mean germination time $($ MGT $)=\left(\sum\left(\mathrm{n}_{1} \mathrm{~T}_{1}+\mathrm{n}_{2} \mathrm{~T}_{2}+\cdots+\mathrm{n}_{\mathrm{k}} \mathrm{T}_{\mathrm{k}}\right)\right) /\left(\sum\left(\mathrm{n}_{1}+\mathrm{n}_{2}+\cdots+\mathrm{n}_{\mathrm{k}}\right)\right) \times 100$

where $\mathrm{n}$ is the number of newly germinated seeds, and $\mathrm{T}$ is the time from starting the experiment.

Seedling vigor index $(\mathrm{SVI})=$ Seedling length $\times$ Germination percentage

Besides shoot length, the root length and fresh weight of seedlings were recorded. Additionally, ten seedlings were dried in oven at $80^{\circ} \mathrm{C}$ for $24 \mathrm{~h}$ and then weighed.

\subsection{Field Trial}

\subsubsection{Experimental Site and Agricultural Practices}

Two field experiments were conducted in the designated area for maize production at Abu-Hammad District, Sharqia, Egypt (30 $\left.32^{\prime} \mathrm{N}, 31^{\circ} 36^{\prime} \mathrm{E}\right)$ during the two summer seasons of 2019 and 2020. The experimental site is hot and arid with no rainfall events during maize growing seasons, which is typical of the summer season in Egypt (Table 1). Before sowing in both seasons, soil samples were collected at three soil depth intervals of 0-30, 30-60, 
and 60-90 $\mathrm{cm}$ to analyze chemical and physical properties (Table 2). Based on the optimal period of maize cultivation in the region, sowing was conducted on the first of May in both years with faba bean (Vicia faba) as the preceding crop. Standard agronomic practices including drip irrigation and pest and disease control were applied as recommended for growing maize in the region. Before sowing, $30 \mathrm{~kg} \mathrm{P}$ per ha as super-phosphate $\left(15.5 \% \mathrm{P}_{2} \mathrm{O}_{5}\right)$ and $95 \mathrm{~kg} \mathrm{~K}$ per ha as potassium sulphate $\left(48 \% \mathrm{~K}_{2} \mathrm{O}\right)$. Additionally, $285 \mathrm{~kg} \mathrm{~N}$ per ha as ammonium sulphate $(20.5 \% \mathrm{~N})$ were applied.

Table 1. Monthly average minimum temperature (Min.), maximum temperature (Max.), cumulative growing degree day (GDD), relative humidity (RH) and total precipitation (Prec.) in 2019 and 2020 growing seasons as well as 20-yr monthly averages (2001-2020).

\begin{tabular}{|c|c|c|c|c|c|}
\hline Month & Min. $\left({ }^{\circ} \mathrm{C}\right)$ & $\operatorname{Max} .\left({ }^{\circ} \mathrm{C}\right)$ & $\operatorname{GDD}^{1}\left({ }^{\circ} \mathrm{C}\right)$ & RH. (\%) & Prec. $(\mathrm{mm})$ \\
\hline \multicolumn{6}{|c|}{ First growing season (2019) } \\
\hline May & 22.2 & 34.1 & 562.6 & 46 & 0 \\
\hline June & 24.7 & 35.3 & 600.0 & 49 & 0 \\
\hline July & 24.9 & 35.8 & 630.9 & 55 & 0 \\
\hline August & 25.8 & 35.3 & 498.5 & 59 & 0 \\
\hline \multicolumn{6}{|c|}{ Second growing season (2020) } \\
\hline May & 20.8 & 34.3 & 544.1 & 42 & 0 \\
\hline June & 23.3 & 35.3 & 579.0 & 49 & 0 \\
\hline July & 24.8 & 35.9 & 630.9 & 54 & 0 \\
\hline August & 25.4 & 35.6 & 508.0 & 56 & 0 \\
\hline \multicolumn{6}{|c|}{20 -yr average } \\
\hline May & 18.9 & 32.4 & & 45 & 0 \\
\hline June & 21.2 & 34.5 & & 47 & 0 \\
\hline July & 23.1 & 35.1 & & 57 & 0 \\
\hline August & 20.3 & 31.4 & & 61 & 0 \\
\hline
\end{tabular}

${ }^{1}$ Growing degree day was calculated from daily minimum and maximum temperature based on $10{ }^{\circ} \mathrm{C}$ base temperature and accumulated for each month.

Table 2. Chemical and physical properties of the experimental field soil (averaged over two seasons: 2019 and 2020).

\begin{tabular}{|c|c|c|c|c|c|c|}
\hline $\begin{array}{l}\text { Soil } \\
\text { Depth } \\
\text { (cm) }\end{array}$ & $\begin{array}{c}\text { Soil Bulk } \\
\text { Density } \\
\left(\mathrm{g} \mathrm{cm}^{-3}\right)\end{array}$ & $\begin{array}{c}\text { Field } \\
\text { Capacity } \\
(\%)\end{array}$ & $\begin{array}{c}\text { Wilting } \\
\text { Point } \\
(\%)\end{array}$ & $\begin{array}{c}\text { Available } \\
\text { Moisture } \\
(\%)\end{array}$ & $\mathrm{pH}$ & $\begin{array}{c}\text { Calcium } \\
\text { Carbonate } \\
(\%)\end{array}$ \\
\hline $0-30$ & 1.47 & 13.51 & 6.75 & 6.76 & 7.95 & 0.42 \\
\hline $30-60$ & 1.52 & 12.23 & 6.11 & 6.12 & 7.91 & 0.40 \\
\hline $60-90$ & 1.56 & 12.11 & 6.05 & 6.05 & 7.80 & 0.40 \\
\hline $\begin{array}{l}\text { Soil } \\
\text { Depth } \\
\text { (cm) }\end{array}$ & $\begin{array}{c}\text { Organic } \\
\text { Matter } \\
(\%)\end{array}$ & $\begin{array}{c}E C \\
\left(\mathrm{dS} \mathrm{m}^{-1}\right)\end{array}$ & $\begin{array}{c}\text { Sand } \\
(\%)\end{array}$ & $\begin{array}{l}\text { Silt } \\
(\%)\end{array}$ & $\begin{array}{c}\text { Clay } \\
(\%)\end{array}$ & Texture \\
\hline $0-30$ & 0.47 & 1.63 & 47.95 & 14.03 & 38.02 & Sandy clay \\
\hline $30-60$ & 0.35 & 1.60 & 48.19 & 13.81 & 38.00 & Sandy clay \\
\hline $60-90$ & 0.31 & 1.53 & 48.23 & 13.87 & 37.90 & Sandy clay \\
\hline
\end{tabular}

\subsubsection{Experimental Design and Treatments}

Split-plot experimental design was performed with three replications for this study. Main plots were assigned for irrigation regimes, while seed priming treatments were randomly distributed into sub-plots. Four irrigation regimes were applied; 120, 100, 80 and $60 \%$ of the estimated crop evapotranspiration (ETc). Additionally, two seed priming treatments were performed, i.e., hydro-priming and hardening using the same protocols applied for laboratory trial in comparison with unprimed seed. The main plots were separated by an alley of 3-m wide, and split-plots were separated by a 1.5-m alley to 
prevent water leakage (Figure 1). The size of each experimental plot was $19.5 \mathrm{~m}^{2}$ containing six rows, 5-m long and $0.65 \mathrm{~m}$ wide, with $0.25 \mathrm{~m}$ hill spacing giving a planting density of 6.2 plants $\mathrm{m}^{-2}$. The drip irrigation system was used to meet the goals of the study. The drip pipes and emitters were spaced at 0.65 and $0.3 \mathrm{~m}$, respectively. Irrigation water quantity was measured independently for each irrigation regime using flow meter. Irrigation scheduling was based on ETc replacement according to the crop coefficient approach [11]. ETc was calculated by multiplying the daily reference evapotranspiration (ETo) by FAO crop coefficients $(\mathrm{Kc})$ of maize [11]. Daily reference evapotranspiration (ETo) was calculated from weather data using the FAO-56 standardized Penman-Monteith equation as stated in [11]. Daily meteorological data, including maximum and minimum temperature, wind speed, and dew point temperature, were obtained from a weather station located at the experimental site and were used for calculating ETo. The values of Kc for maize as recommended by FAO-56 were adjusted based on actual values of climatic conditions including relative humidity and wind speed in the experimental site. The adjusted Kc values in the growing season varied 0.20, 1.2 and 0.35 in the initial, mid and late-season stages, respectively. The cumulative amount of full irrigation regime $(100 \%$ ETc) was 576.5 and $582.4 \mathrm{~mm} \mathrm{ha}^{-1}$ during the first and second growing seasons, respectively. The amount of irrigation water was increased/decreased by $20 \%$ for various irrigation levels of 60 to $120 \%$ ETc. The irrigation treatments were started after two weeks from sowing in both seasons, and a blank application of $75 \mathrm{~mm}$ was applied to all plots to ensure full germination and complete seedling establishment. Irrigation was terminated at the end of the growing season, approximately 20 days before harvest (Mid-August).



Figure 1. Layout of the experiment presenting four irrigation regimes in main plots and seed priming treatments in sub-plots.

\subsubsection{Field Measurements}

During the grain-filling period (90 DAS), relative water content (RWC) was recorded. Fresh leaves were collected, weighed (FW) and then soaked in water for three hours, and their turgid weights (TW) were calculated. The samples were dried in oven at $80^{\circ} \mathrm{C}$ for $24 \mathrm{~h}$ and weighed (DW). It was determined as follows: RWC $(\%)=(\mathrm{FW}-\mathrm{DW}) /(\mathrm{TW}-$ $\mathrm{DW}) \times 100$. After physiological maturity $(\sim 115$ days after sowing $)$, ten guarded plants were randomly harvested from the second inner two rows of each plot to determine plant height $(\mathrm{cm})$, cob height $(\mathrm{cm})$, cob length $(\mathrm{cm})$, number of rows per cob, number of kernels 
per row, kernel weight per cob, shelling percentage and 100-kernel weight (g) adjusted at $15.5 \%$ grain moisture. The central two rows of each plot were harvested by hand at ground level then sun-dried for 10 days. Grain yield was determined from shelled cobs and was adjusted to $15.5 \%$ moisture content. Crop water productivity (CWP) was calculated as follows: CWP $=($ Grain yield $) /($ Etc + Pr $)$, where: CWP is crop water productivity $\left(\mathrm{kg} \mathrm{m}^{-3}\right)$, grain yield $\left(\mathrm{kg} \mathrm{ha}^{-1}\right)$, ETc is the crop evapotranspiration $\left(\mathrm{m}^{3} \mathrm{ha}^{-1}\right)$ and Pr is a uniform amount of water was applied to all plots to ensure full germination and complete seedlings establishment $\left(750 \mathrm{~m}^{3}\right)$.

\subsection{Statistical Analysis}

Data of seed germinability and seedling vigor tests were subjected to the analysis of variance of completely randomized design. The experimental data of both growing seasons were subjected to split-plot analysis. Quadratic-plateau regression model was performed between grain yield and irrigation water amount for the three priming treatments using program of GraphPad Prism. ANOVA and principal component analyses were performed using R statistical software version 3.6.1.

\section{Results}

\subsection{Laboratory Measurements}

Seed priming treatments comprising hydro-priming and hardening significantly increased germination percentage, germination index, energy of germination, root length, and seedling fresh and dry weight as well as the seedling vigor index compared with unprimed seeds (Table 3). Seed priming treatments accelerated the germination process and significantly lowered germination time compared to the unprimed treatment as shown in Table 3. Noticeably, seed hardening displayed the highest enhancing of germination percentage by $20 \%$, germination index by $78 \%$, energy of germination by $33 \%$, shoot length by $79 \%$, root length by $21 \%$, seedling fresh weight by $8 \%$, seedling dry weight by $14 \%$ and seedling vigor index by $64 \%$ as well as shortened germination time by $9 \%$ compared with unprimed seeds.

Table 3. Germination percentage (GP, \%), germination index (GI, seed day ${ }^{-1}$ ), energy of germination (EG), mean germination time (MGT, day), shoot length (SL, cm), root length (RL, cm), seedling fresh weight (SFW, mg), seedling dry weight (SDW, $\mathrm{mg}$ ) and seedling vigor index (SVI) of maize seeds as affected by seed priming treatments.

\begin{tabular}{|c|c|c|c|c|c|}
\hline Treatment & GP (\%) & $\begin{array}{c}\text { GI (seed } \\
\text { day }^{-1} \text { ) }\end{array}$ & EG & MGT (day) & $\mathrm{SL}(\mathrm{cm})$ \\
\hline Unprimed & $81.33^{b}$ & $12.91^{\mathrm{b}}$ & $2.88^{\mathrm{b}}$ & $6.70^{\mathrm{a}}$ & $5.08^{b}$ \\
\hline Hydro-priming & $90.66^{\mathrm{a}}$ & $20.02^{a}$ & $3.33^{a}$ & $6.17^{b}$ & $6.97^{b}$ \\
\hline Hardening & $97.33^{a}$ & $22.99^{a}$ & $3.84^{\mathrm{a}}$ & $6.08^{b}$ & $9.11^{\mathrm{a}}$ \\
\hline ANOVA & 0.018 & 0.002 & 0.018 & 0.007 & 0.039 \\
\hline Treatment & $\mathrm{RL}(\mathrm{cm})$ & SFW (mg) & SDW (mg) & SVI & \\
\hline Unprimed & $15.79^{b}$ & $635.20^{b}$ & $203.70^{b}$ & $1697.4^{\mathrm{c}}$ & \\
\hline Hydro-priming & $17.65^{\mathrm{ab}}$ & $658.62^{a}$ & $228.12^{a}$ & $2237.2^{b}$ & \\
\hline Hardening & $19.16^{\mathrm{a}}$ & $687.45^{a}$ & $232.04^{\mathrm{a}}$ & $2790.6^{a}$ & \\
\hline ANOVA & 0.032 & 0.021 & 0.026 & 0.019 & \\
\hline
\end{tabular}

Means followed by different letters in the same column differ significantly by LSD $(p<0.05)$. 


\subsection{Grain Yield and Attributed Traits}

The results revealed that increasing irrigation water from 100\% ETc up to $120 \%$ ETc displayed non-significant increment in RWC, plant height, cob height, cob length, number of rows per cob, number of kernels per row, kernel weight per cob, shelling percentage, 100-kernel weight, grain yield and harvest index (Tables 4 and 5). On the other hand, exposing maize plants to moderate drought stress ( $80 \%$ ETc) or severe drought stress $(60 \%$ ETc) significantly decreased all aforementioned traits compared with plants in well-watered (100 and 120\% ETc) conditions (Tables 4 and 5). Additionally, the adverse effects of severe drought exceeded those of moderate drought stress.

Table 4. Impact of irrigation regimes and seed priming treatments on relative water content (RWC), plant height, cob height, cob length, number of rows per cob and number of kernels per row during the growing seasons of 2019 and 2020.

\begin{tabular}{|c|c|c|c|c|c|c|c|}
\hline \multirow{2}{*}{\multicolumn{2}{|c|}{ Studied Factors }} & \multicolumn{2}{|c|}{ RWC } & \multicolumn{2}{|c|}{ Plant Height (cm) } & \multicolumn{2}{|c|}{ Cob Height (cm) } \\
\hline & & 2019 & 2020 & 2019 & 2020 & 2019 & 2020 \\
\hline \multicolumn{8}{|c|}{ Irrigation regimes (I) } \\
\hline & & $72.45^{\mathrm{A}}$ & $73.34^{\mathrm{A}}$ & $315.63^{A}$ & $304.87^{\mathrm{A}}$ & $144.01^{\mathrm{A}}$ & $151.21^{\mathrm{A}}$ \\
\hline & & $70.56^{\mathrm{A}}$ & $72.07^{\mathrm{A}}$ & $310.06^{\mathrm{A}}$ & $297.21^{\text {A }}$ & $144.40^{\mathrm{A}}$ & $148.97^{\mathrm{A}}$ \\
\hline & & $62.37^{\mathrm{B}}$ & $61.70^{\mathrm{B}}$ & $258.71^{\mathrm{B}}$ & $279.89^{\mathrm{B}}$ & $136.43^{\mathrm{B}}$ & $135.68^{\mathrm{B}}$ \\
\hline & & $57.19^{C}$ & $57.60^{\mathrm{C}}$ & $212.60^{C}$ & $237.97^{C}$ & $109.44^{C}$ & $119.85^{\mathrm{C}}$ \\
\hline \multicolumn{8}{|c|}{ Priming treatments $(P)$} \\
\hline & & $61.65^{\mathrm{b}}$ & $57.70^{\mathrm{b}}$ & 274.58 & 277.00 & $136.22^{a}$ & $134.99^{a}$ \\
\hline Hyd & & $66.70^{\mathrm{a}}$ & $69.99^{a}$ & 276.61 & 279.38 & $132.68^{b}$ & $133.35^{b}$ \\
\hline & & $68.58^{a}$ & $70.84^{\mathrm{a}}$ & 275.06 & 280.57 & $131.81^{\mathrm{b}}$ & $131.44^{\mathrm{c}}$ \\
\hline ANOVA & $\mathrm{df}$ & \multicolumn{6}{|c|}{$p$-value of main effects and their interaction } \\
\hline I & 3 & 0.006 & 0.005 & $<0.001$ & $<0.001$ & $<0.001$ & $<0.001$ \\
\hline $\mathrm{P}$ & 2 & 0.017 & $<0.001$ & 0.23 & 0.36 & 0.012 & 0.027 \\
\hline $\mathrm{I} \times \mathrm{P}$ & 6 & 0.048 & 0.037 & 0.072 & 0.081 & 0.73 & 0.62 \\
\hline \multirow{2}{*}{\multicolumn{2}{|c|}{ Studied Factors }} & \multicolumn{2}{|c|}{ Cob Length $(\mathrm{cm})$} & \multicolumn{2}{|c|}{ Number of Rows $\mathrm{Cob}^{-1}$} & \multicolumn{2}{|c|}{ Number of Kernels Row ${ }^{-1}$} \\
\hline & & 2019 & 2020 & 2019 & 2020 & 2019 & 2020 \\
\hline \multicolumn{8}{|c|}{ Irrigation regimes (I) } \\
\hline & & $20.77^{\mathrm{A}}$ & $19.34^{\mathrm{A}}$ & $13.58^{\mathrm{A}}$ & $13.39^{\mathrm{A}}$ & $42.17^{\mathrm{A}}$ & $34.50^{\mathrm{A}}$ \\
\hline & & $20.67^{A}$ & $18.28 \mathrm{AB}$ & $13.18^{\mathrm{AB}}$ & $12.71^{\mathrm{AB}}$ & $41.57^{\mathrm{A}}$ & $33.24^{\mathrm{A}}$ \\
\hline & & $19.14^{\mathrm{B}}$ & $17.64^{\mathrm{AB}}$ & $13.05^{\mathrm{AB}}$ & $12.3^{\mathrm{BC}}$ & $33.31^{\mathrm{B}}$ & $25.04^{\mathrm{B}}$ \\
\hline & & $16.94^{\mathrm{C}}$ & $15.16^{\mathrm{C}}$ & $12.63^{\mathrm{B}}$ & $11.66^{\mathrm{C}}$ & $26.4^{\mathrm{C}}$ & $19.03^{C}$ \\
\hline \multicolumn{8}{|c|}{ Priming treatments $(\mathrm{P})$} \\
\hline & & $17.68^{b}$ & $16.42^{b}$ & $12.74^{\mathrm{b}}$ & $11.32^{b}$ & $35.43^{b}$ & $24.55^{c}$ \\
\hline Hyd & & $19.53^{\mathrm{a}}$ & $18.39^{a}$ & $13.43^{\mathrm{a}}$ & $12.95^{\mathrm{a}}$ & $35.95^{a b}$ & $30.47^{b}$ \\
\hline & & $19.68^{a}$ & $18.01^{\mathrm{a}}$ & $13.16^{\mathrm{a}}$ & $13.27^{\mathrm{a}}$ & $36.21^{\mathrm{a}}$ & $31.84^{\mathrm{a}}$ \\
\hline ANOVA & $\mathrm{df}$ & \multicolumn{6}{|c|}{$p$-value of main effects and their interaction } \\
\hline I & 3 & 0.019 & $<0.001$ & 0.001 & 0.008 & 0.008 & $<0.001$ \\
\hline $\mathrm{P}$ & 2 & 0.016 & 0.003 & 0.026 & 0.001 & 0.003 & 0.001 \\
\hline $\mathrm{I} \times \mathrm{P}$ & 6 & 0.025 & 0.041 & 0.035 & 0.044 & 0.013 & 0.002 \\
\hline
\end{tabular}

Means followed by different letters at the same factor differ significantly by LSD $(p<0.05)$.

Evidently, seed hydro-priming and hardening significantly increased all aforementioned traits except cob height, which was lowered compared with unprimed plants; however, this could be considered an advantageous effect (Tables 4 and 5). The interaction between irrigation regimes and seed priming is presented in Figures 2 and 3 . There was no significant difference between seed hydro-priming and hardening under well-watered conditions (100 and 120\% ETc) for grain yield and most related traits (Figures 2 and 3), while seed priming treatments displayed significant differences under moderate and severe 
drought conditions ( 80 and $60 \%$ ETc). Primed treatments under moderate drought stress $(80 \%$ ETc) displayed non-significant reduction in RWC, cob length, number of rows per cob, shelling percentage, 100-kernel weight and harvest index compared with unprimed treatment under full irrigation requirement $(100 \% \mathrm{ETc})$ conditions.

Table 5. Impact of irrigation regimes and seed priming treatments on kernel weight per cob, shelling percentage, 100-kernel weight, grain yield, harvest index and crop water productivity (CWP) during the growing seasons of 2019 and 2020.

\begin{tabular}{|c|c|c|c|c|c|c|c|}
\hline \multirow{2}{*}{\multicolumn{2}{|c|}{ Studied Factors }} & \multicolumn{2}{|c|}{ Kernel Weight cob $^{-1}$} & \multicolumn{2}{|c|}{ Shelling Percentage } & \multicolumn{2}{|c|}{ 100-Kernel Weight (g) } \\
\hline & & 2019 & 2020 & 2019 & 2020 & 2019 & 2020 \\
\hline \multicolumn{8}{|c|}{ Irrigation regimes (I) } \\
\hline \multicolumn{2}{|c|}{$120 \%$ ETc } & $131.31^{\mathrm{A}}$ & $123.99 \mathrm{~A}$ & $75.37^{\mathrm{A}}$ & $72.87^{\mathrm{A}}$ & $27.03^{\mathrm{A}}$ & $27.63^{\mathrm{A}}$ \\
\hline \multicolumn{2}{|c|}{$100 \% \mathrm{ETc}$} & $124.57^{\mathrm{A}}$ & $111.76^{\mathrm{A}}$ & $73.38^{\mathrm{A}}$ & $72.81^{\mathrm{A}}$ & $26.04^{\mathrm{AB}}$ & $26.13^{\mathrm{A}}$ \\
\hline \multicolumn{2}{|c|}{$80 \%$ ETc } & $78.24^{\mathrm{B}}$ & $81.73^{\text {B }}$ & $69.26^{\mathrm{AB}}$ & $65.80^{\mathrm{B}}$ & $25.38^{\mathrm{B}}$ & $23.48^{\mathrm{B}}$ \\
\hline \multicolumn{2}{|c|}{$60 \%$ ETc } & $65.32^{\mathrm{B}}$ & $55.79^{\mathrm{C}}$ & $65.27^{\mathrm{B}}$ & $61.93^{\text {B }}$ & $23.13^{C}$ & $23.41^{\mathrm{B}}$ \\
\hline \multicolumn{8}{|c|}{ Priming treatments $(\mathrm{P})$} \\
\hline \multicolumn{2}{|c|}{ Unprimed } & $89.25^{c}$ & $82.18^{c}$ & $68.65^{b}$ & $65.55^{b}$ & $24.57^{b}$ & $21.47^{b}$ \\
\hline \multicolumn{2}{|c|}{ Hydro-priming } & $100.50^{b}$ & $96.12^{b}$ & $71.60^{a}$ & $69.77^{a}$ & $25.50 \mathrm{ab}$ & $27.91^{\mathrm{a}}$ \\
\hline \multicolumn{2}{|c|}{ Hardening } & $106.29^{a}$ & $101.65^{\mathrm{a}}$ & $72.22^{\mathrm{a}}$ & $69.80^{\mathrm{a}}$ & $26.11^{\mathrm{a}}$ & $26.10^{\mathrm{a}}$ \\
\hline ANOVA & $\mathrm{df}$ & \multicolumn{6}{|c|}{$p$-value of main effects and their interaction } \\
\hline $\mathrm{I}$ & 3 & 0.001 & $<0.001$ & 0.035 & 0.032 & 0.001 & 0.004 \\
\hline $\mathrm{P}$ & 2 & 0.038 & 0.001 & 0.031 & 0.015 & 0.012 & $<0.001$ \\
\hline $\mathrm{I} \times \mathrm{P}$ & 6 & 0.046 & 0.025 & 0.039 & 0.036 & 0.025 & 0.045 \\
\hline \multirow{2}{*}{\multicolumn{2}{|c|}{ Studied Factors }} & \multicolumn{2}{|c|}{ Grain Yield ha ${ }^{-1}(\mathrm{~kg})$} & \multicolumn{2}{|c|}{ Harvest Index (\%) } & \multicolumn{2}{|c|}{$\mathrm{CWP}\left(\mathrm{kg} \mathrm{m}^{-3}\right)$} \\
\hline & & 2019 & 2020 & 2019 & 2020 & 2019 & 2020 \\
\hline \multicolumn{8}{|c|}{ Irrigation regimes (I) } \\
\hline \multirow{4}{*}{\multicolumn{2}{|c|}{$\begin{array}{c}120 \% \text { ETc } \\
100 \% \text { ETc } \\
80 \% \text { ETc } \\
60 \% \text { ETc }\end{array}$}} & $7351.2^{\mathrm{A}}$ & $7597.9^{\mathrm{A}}$ & $35.88^{\mathrm{AB}}$ & $35.62 \mathrm{AB}$ & $1.06^{\mathrm{C}}$ & $1.09^{\mathrm{B}}$ \\
\hline & & $7246.7^{\mathrm{A}}$ & $7492.8^{\mathrm{A}}$ & 38.89 A & $37.24^{\mathrm{A}}$ & $1.25^{\mathrm{A}}$ & $1.29^{\mathrm{A}}$ \\
\hline & & $5330.5^{\mathrm{B}}$ & $5982.8^{\mathrm{B}}$ & $34.74 \mathrm{AB}$ & $33.83 \mathrm{AB}$ & 1.15 & $1.28^{\mathrm{A}}$ \\
\hline & & $4249.4^{\mathrm{C}}$ & $4250.1^{\mathrm{C}}$ & $30.11^{\text {B }}$ & $27.39^{\text {B }}$ & $1.22^{\mathrm{A}}$ & $1.22^{\mathrm{A}}$ \\
\hline \multicolumn{8}{|c|}{ Priming treatments $(\mathrm{P})$} \\
\hline \multirow{3}{*}{\multicolumn{2}{|c|}{$\begin{array}{c}\text { Unprimed } \\
\text { Hydro-priming } \\
\text { Hardening }\end{array}$}} & $5675.8^{\mathrm{b}}$ & $5904.3^{b}$ & $33.35^{\mathrm{b}}$ & $32.53^{b}$ & $1.09^{b}$ & $1.13^{c}$ \\
\hline & & $6215.2^{\mathrm{a}}$ & $6384.6^{\mathrm{a}}$ & $35.53^{a}$ & $34.81^{\mathrm{a}}$ & $1.21^{\mathrm{a}}$ & $1.23^{b}$ \\
\hline & & $6242.3^{\mathrm{a}}$ & $6703.9^{a}$ & $36.84^{\mathrm{a}}$ & $34.17^{\mathrm{a}}$ & $1.21^{\mathrm{a}}$ & $1.31^{\mathrm{a}}$ \\
\hline ANOVA & $\mathrm{df}$ & \multicolumn{6}{|c|}{$p$-value of main effects and their interaction } \\
\hline I & 3 & $<0.001$ & $<0.001$ & 0.040 & 0.031 & $<0.001$ & 0.0046 \\
\hline $\mathrm{P}$ & 2 & 0.004 & 0.002 & 0.039 & 0.036 & $<0.001$ & $<0.001$ \\
\hline $\mathrm{I} \times \mathrm{P}$ & 6 & 0.035 & 0.028 & 0.026 & 0.045 & 0.044 & 0.028 \\
\hline
\end{tabular}

Means followed by different letters at the same factor differ significantly by LSD $(p<0.05)$. 

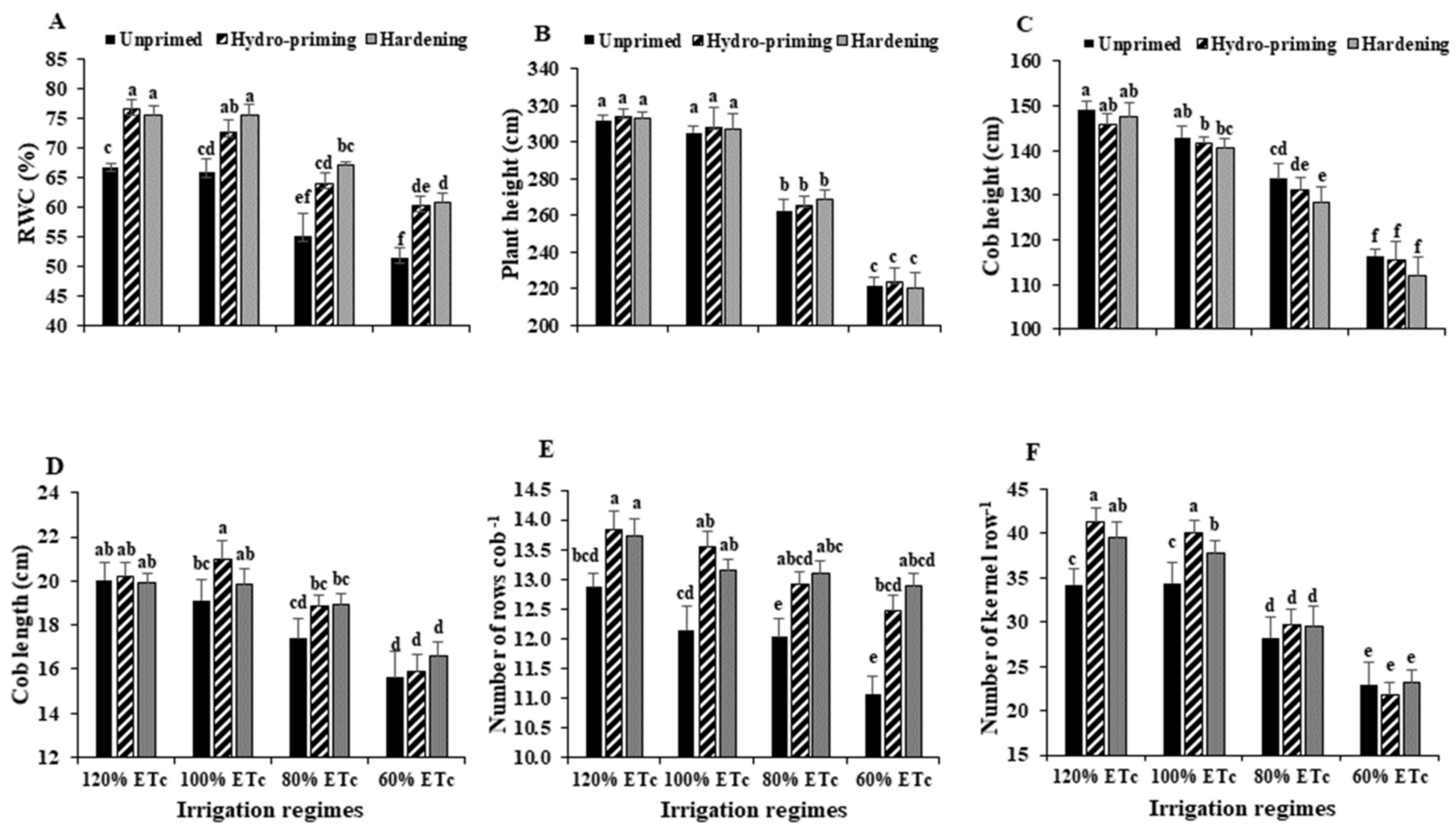

Figure 2. Influence of seed priming treatments on relative water content (RWC) (A), plant height (B), cob height (C), cob length (D), number of rows per cob (E) and number of kernels per row (F) of maize grown under four irrigation regimes averaged over two growing seasons (2019 and 2020). The bars on the top of the columns represent the SE, and different letters on the column differ significantly by $\operatorname{LSD}(p<0.05)$.
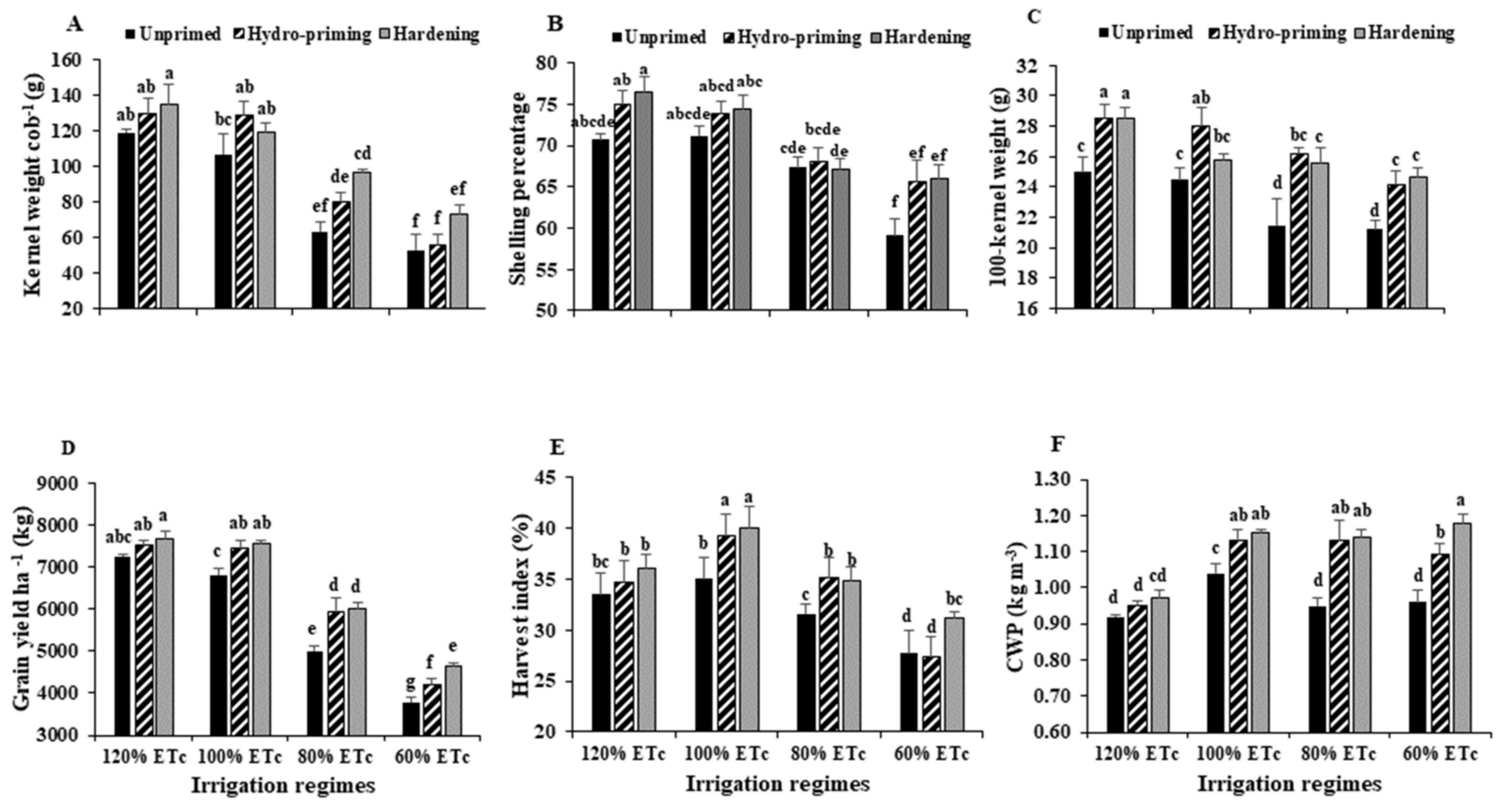

Figure 3. Influence of seed priming treatments on kernel weight per cob (A), shelling percentage (B), 100-kernel weight (C), grain yield (D), harvest index (E) and crop water productivity $(\mathbf{F})$ of maize grown under four irrigation regimes averaged over two growing seasons (2019 and 2020). The bars on the top of the columns represent the SE, and different letters on the column differ significantly by LSD $(p<0.05)$. 


\subsection{Crop Water Productivity (CWP)}

Increasing irrigation water to $120 \%$ ETc significantly decreased CWP compared with $100 \%$ ETc. While drought stress (60 and 80\% ETc) significantly increased CWP compared to well-watered plants (100\% and $120 \%$ ETc). Seed hydro-priming and hardening significantly enhanced CWP compared with unprimed treatment (Table 5). On the subject of interaction effects, increasing irrigation water from $100 \%$ ETc up to $120 \%$ ETc had significant negative effect on CWP under all seed priming treatments (Figure 3). Moreover, no significant difference was observed among seed priming treatments for CWP under over-irrigated irrigation $(120 \% \mathrm{ETc})$, while there was significant difference under well-irrigated (100\%ETc) and drought stress conditions (60 and $80 \% \mathrm{ETc}$ ) as seed priming significantly increased CWP compared to unprimed seeds.

\subsection{Grain Yield Response to Irrigation Regimes}

Grain yield was plotted against irrigation regimes for the three seed priming treatments to describe their relationship by regression model (Figure 4). The three priming treatments displayed quadratic convex diminishing responses. The expected optimum irrigation regimes for unprimed, hydro-priming and hardening treatments were 645,614 and $624 \mathrm{~mm}$, which could produce 7186, 7468 and $7612 \mathrm{~kg} \mathrm{ha}^{-1}$, respectively. This indicates that hydro-priming and hardening treatments produce greater grain yield with less irrigation amounts compared with unprimed treatment, particularly under water deficit conditions as shown in (Figure 4).

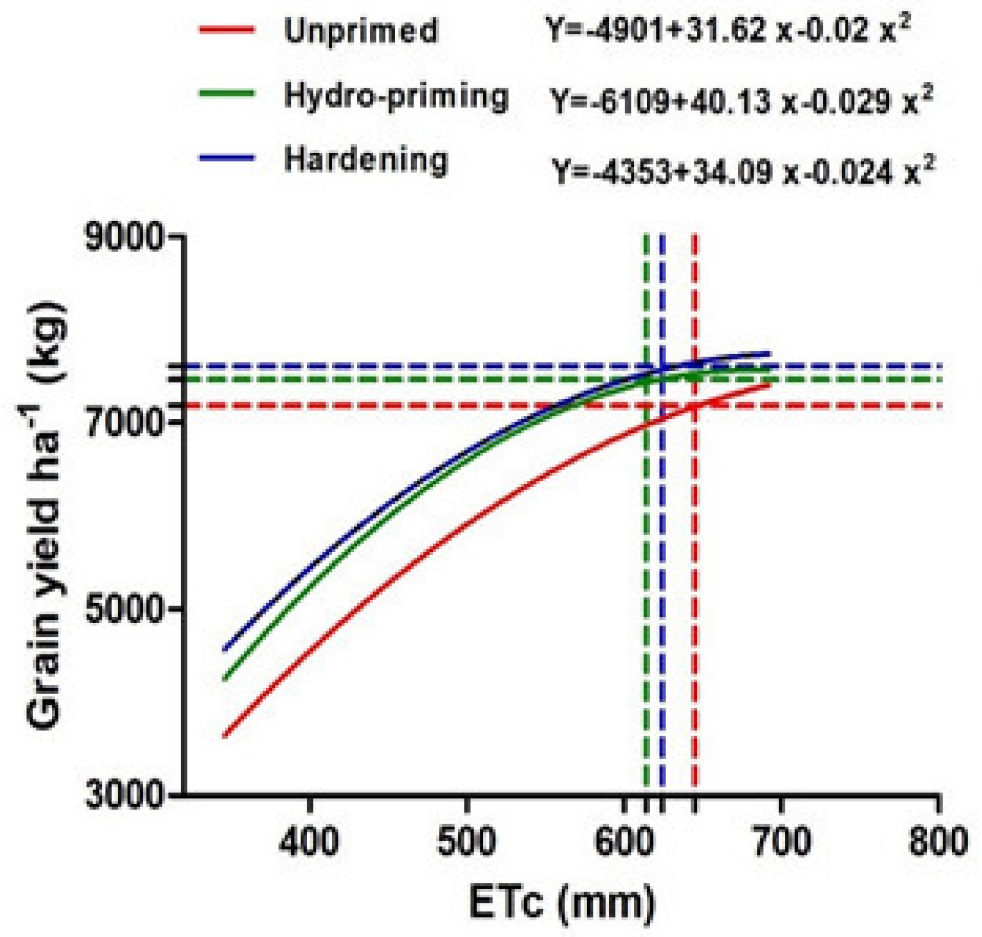

Figure 4. Grain yield response to irrigation water amount and identifying optimum irrigation amount for the three priming treatments. The dotted vertical lines indicate the optimum irrigation amount, and horizontal lines indicate the expected grain yield for each priming treatment.

\subsection{Interrelationship among Measured Traits}

The association between all measured traits was estimated by principal component analysis (PCA). The first two components of PCA presented about $89.15 \%$ of variability, with the first and second PCA explained $76.64 .16 \%$ and $12.51 \%$ of the total variation among all traits, respectively (Figure 5). Generally, adjacent or parallel vectors indicate a strong positive association between traits, while vectors towards the sides expressed a weak 
relationship and those placed approximately opposite $\left(\right.$ at $\left.180^{\circ}\right)$ displayed highly negative association. A strong positive association was detected among RWC, grain yield, number of kernels per row, number of rows per cob, 100-kernal weight, kernel weight per cob, plant height, cob length and harvest index. Moreover, a negative association was proven between grain yield and CWP. Furthermore, PC1 separated the irrigation regimes into two groups; well-watered treatments $(100 \%$ and $120 \%$ ETc) were located on the positive side, while drought stress treatments ( $60 \% 80 \%$ ETc) were on the negative side. Furthermore, yield-related traits are associated with hydro-priming and hardening under well-watered irrigation regimes.

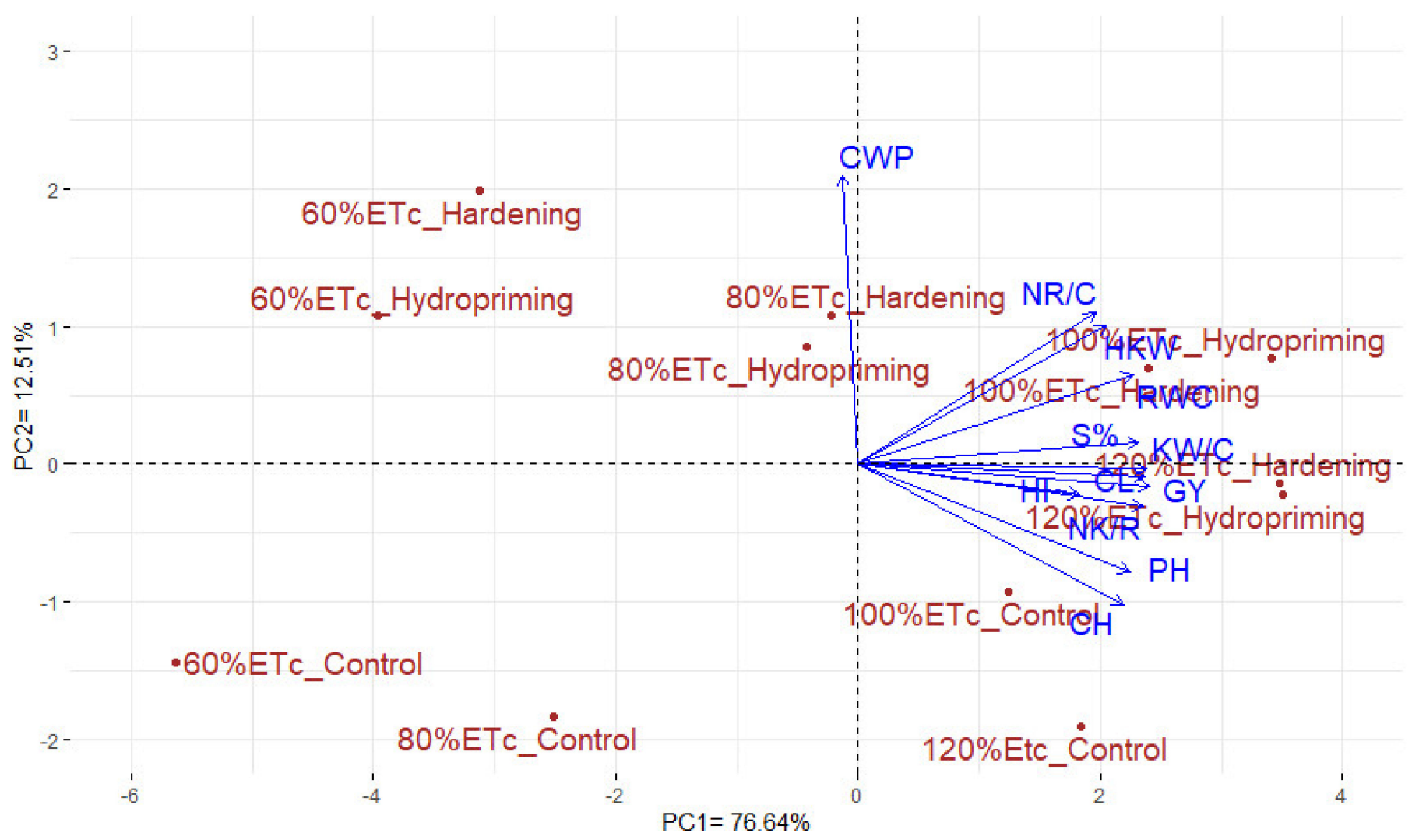

Figure 5. Biplot of principal components for studied traits of maize grown under four irrigation regimes and three seed priming treatments over two growing seasons (2019 and 2020). RWC is relative water content, $\mathrm{PH}$ is plant height, $\mathrm{CH}$ is cob height, $C L$ is cob length, NR/C is number of rows per cob, NK/R is number of kernels per row, KW/C is kernel weight per cob, $\mathrm{S} \%$ is shelling percentage, HKW is 100-kernel weight, GY is grain yield, $\mathrm{HI}$ is harvest index and CWP is crop water productivity.

\section{Discussion}

The Mediterranean region is greatly affected by climate change and adverse impacts are projected on water resources due to fluctuations in precipitation, particularly in dry regions $[1,45]$. Moreover, the expected variations in climate variables will negatively affect ETo $[14,15]$. Therefore, it is necessary to schedule irrigation requirements periodically to achieve high yield without wasting water through excess irrigation or inducing plants to destructive tendencies through drought stress. In the present study, four irrigation regimes were applied $(120,100,80$ and $60 \% \mathrm{ETc})$ to investigate the impact of excessive or deficit irrigation conditions on maize grain yield and CWP in arid environments. Indeed, increasing CWP is required, particularly in arid and semi-arid regions, to preserve limited irrigation water [46]. The results revealed that increasing irrigation water from $100 \%$ up to $120 \%$ ETc did not significantly increase grain yield and contributing traits, while it decreased 
CWP (Tables 4 and 5). In this context, Irmak, et al. [47] and Liu, et al. [48] reported that excessive irrigation water by $20 \%$ over full irrigation did not cause a significant increase of maize grain yield and CWP compared to full irrigation levels. On the other hand, Bozkurt and Yazar [49] and Kuscu, et al. [50] disclosed that over-irrigation by about $20 \%$ over full irrigation increased maize grain yield.

Reducing irrigation water from $100 \%$ to $80 \%$ or $60 \%$ ETc gradually decreased grain yield and all attributed traits (Tables 4 and 5). Admittedly, deficit irrigation conditions during the vegetative stage decreased grain filling rate and kernel weight [51-53]. Moreover, water deficit during the reproductive stage reduced fertilization of ovules and, accordingly, the number of kernels per cob and grain yield [54]. Additionally, the water deficit caused reduction in the mobilization of carbohydrates from stem and leaf sheaths to grains, which led to a reduction in kernel weight per cob [55]. Furthermore, drought stress significantly decreased harvest index as a result of grain yield reduction (Table 5). In this context, Rafiee and Kalhor [56] stated that the harvest index significantly decreased due to water stress and grain yield was more sensitive than total dry matter to water stress. Correspondingly, the negative impact of water scarcity on grain yield and contributing traits was documented by various researchers as Greaves and Wang [57], Wang, et al. [58], Bharathi, et al. [55], Siyami, et al. [59] and Zhang, et al. [53]. Therefore, it is important to assess different approaches that can ameliorate maize stand establishment, growth and productivity under water deficit, particularly in arid environments.

Seed priming is a cost-effective and sustainable approach that can ameliorate crop stand establishment, growth and productivity $[24,25,29]$. In the current study, seed hydropriming and hardening were applied to assess their impacts on maize yield and CWP under excessive, full and deficit irrigation levels. The results of the laboratory trial indicated that the two applied seed priming treatments promoted the germination process and produced more vigorous seedlings (as indicated by earlier germination), higher germination percentage, longer roots and shoots, and heavier fresh and dry weight in comparison with unprimed seeds with the superiority of hardening treatment (Table 3). This stimulation in germination and seedling vigor attributed to metabolic repair during imbibition, modulation of enzymes activities, build-up of germination-enhancing metabolites, accumulation of osmotic adjustment and shortening imbibition lag time [39,40,60]. The obtained findings are in consonance with the results of Hussain, et al. [61], Rehman, et al. [62], Nouman, et al. [63], ur Rehman, et al. [64], and Adhikary and Mandal [65]. They manifested that hydro-priming and hardening treatments accelerated and increased germination percentage, enhanced seed viability and improved seedling vigor parameters. Besides, the results of the field trial of both seasons revealed that seed priming significantly increased RWC, yield components traits (number of rows per cob, number of kernels per row, 100-kernel weight), grain yield, harvest index and CWP compared with unprimed treatment (Tables 4 and 5). Seed priming induced better utilization of water and nutrients during early growth stages due to an improved root system and shoot growth (Table 3). Consequently, seed priming increased crop growth and productivity through enhancing early seedling growth and stand establishment, which increased yield contributing traits. The positive impacts of seed priming on maize growth and yield components produced greater grain yield and thereby higher CWP compared with unprimed treatment. These results are in harmony with previous findings that indicated that seed priming techniques improved yield and attributed traits in diverse field crops [30,44,59,64].

The current study was an attempt to examine whether the seed priming approach could enhance maize grain yield and CWP under water deficit conditions. The interaction effect between irrigation regimes and seed priming showed that seed hydro-priming and hardening treatments improved grain yield, attributed traits and CWP under water deficit conditions compared with unprimed treatment (Figures 2 and 3). Interestingly, seed priming treatments under moderate drought stress (80\% ETc) exhibited a non-significant reduction in RWC, cob length, number of rows per cob, shelling percentage, 100-kernel weight and harvest index compared with unprimed treatment under well-watered $(100 \%$ 
ETc) conditions (Figures 2 and 3). Furthermore, seed hydro-priming significantly increased grain yield under moderate and severe drought stress by 20 and $22.7 \%$, and seed hardening increased grain yield by 19 and 13\% compared to unprimed treatment, respectively. Moreover, seed hydro-priming enhanced CWP under moderate and severe drought stress by 19 and $23 \%$ as well as seed hardening boosted CWP by 18.8 and $14 \%$ compared to unprimed treatment, in the same order. These findings highlight the importance of seed priming, in particular hardening, in alleviating negative effects of drought stress and increasing CWP under water deficit conditions, hence boosting drought tolerance, in maize. Correspondingly, Ref. [66] depicted that seed priming enhances drought tolerance by modifying some enzymes' activities as well as increasing soluble sugar and proline content. Consequently, increasing soluble sugar and proline contents decreases the osmotic potential of plant cells and increases water flux to plant cells and, thereby, RWC [65]. Moreover, seed priming has a vital role in producing vigorous plants with deeper root systems that are able to use available surrounding resources, thus enhancing grain yield. Accordingly, vigorous plants have a great ability to capture resources and are expected to be more tolerant to abiotic stress [25,67].

Grain yield was plotted against irrigation regimes for the three priming treatments to describe their relationship using the regression model (Figure 4). The three priming treatments displayed quadratic convex diminishing responses. The obtained results proved that seed hydro-priming and hardening can save irrigation amounts by producing greater grain yield using lower irrigation water compared with unprimed seeds (Figure 4). Moreover, this greater yield using seed priming could be explained clearly under water stress conditions. These results confirmed the importance of seed priming, in particular hardening, under water deficit conditions. Similarly, Kipkorir, et al. [68], Bozkurt, et al. [69], and Farré and Faci [70] demonstrated a non-linear relationship between grain yield and irrigation level. Furthermore, the results displayed that the expected optimum irrigation amounts to achieve maximum significant grain yield are 645,614 and $624 \mathrm{~mm}$ for unprimed, hydropriming and hardening treatments, which could produce 7186,7468 and $7612 \mathrm{~kg} \mathrm{ha}^{-1}$, respectively. Subsequently, any increment in the expected optimum irrigation amount will not add any further significant increase in grain yield. These results are in consonance with the obtained results of grain yield under over-irrigation regimes $(120 \%$ ETc using $695 \mathrm{~mm} \mathrm{ha}{ }^{-1}$ ) which displayed a non-significant increment in grain yield while decreasing CWP.

\section{Conclusions}

Increasing irrigation water from $100 \%$ up to $120 \%$ ETc did not significantly increase grain yield and attributed traits, while it decreased CWP. On the contrary, exposing maize plants to moderate drought stress $(80 \%$ ETc) or severe drought stress $(60 \%$ ETc) gradually decreased grain yield and related traits compared with well-watered (100 and 120\% ETc) conditions. On the other hand, seed hydro-priming and hardening enhanced maize growth, grain yield and CWP under water deficit conditions through improving seedling establishment. The applied seed priming, particularly hardening, exhibited an important role in mitigating the negative impacts of drought stress and increasing maize grain yield and CWP, hence boosting drought tolerance. This was confirmed by the relationship between irrigation water amount and grain yield by the quadratic regression model. In conclusion, seed hydro-priming and hardening displayed greater grain yield with less irrigation water amounts compared with unprimed seed, particularly under deficit irrigation conditions.

Author Contributions: Conceptualization, A.M.E., A.S.M.E., M.M.A.A. and E.M.; methodology, A.M.E., A.S.M.E., M.M.A.A. and E.M.; software, A.M.E., A.S.M.E., M.M.A.A., M.F.A. and E.M.; validation, A.M.E., A.S.M.E., M.M.A.A., M.F.A. and E.M.; formal analysis, A.M.E., A.S.M.E., M.M.A.A., M.F.A. and E.M.; investigation, A.M.E., A.S.M.E., M.M.A.A. and E.M.; resources, A.M.E., M.F.A. and E.M.; data curation, A.M.E., A.S.M.E., M.M.A.A., M.F.A. and E.M.; writing-original draft preparation, A.M.E., A.S.M.E., M.M.A.A., M.F.A. and E.M.; writing-review and editing, A.M.E., A.S.M.E., 
M.M.A.A., M.F.A. and E.M.; visualization, A.M.E., A.S.M.E., M.M.A.A., M.F.A. and E.M.; supervision, A.M.E., A.S.M.E., M.M.A.A., M.F.A. and E.M.; funding acquisition, A.M.E., A.S.M.E., M.M.A.A., M.F.A. and E.M. All authors have read and agreed to the published version of the manuscript.

Funding: This research received no external funding.

Data Availability Statement: The data presented in this study are available upon request from the corresponding author.

Acknowledgments: The authors wish to thank Zagazig University for the technical and financial support of this research. The authors extend their appreciation to the Taif University for funding this work through Taif University Researchers Supporting Project number (TURSP -2020/111), Taif University, Taif, Saudi Arabia.

Conflicts of Interest: The authors declare no conflict of interest.

\section{References}

1. Ozturk, T.; Ceber, Z.P.; Türkeş, M.; Kurnaz, M.L. Projections of climate change in the Mediterranean Basin by using downscaled global climate model outputs. Int. J. Climatol. 2015, 35, 4276-4292. [CrossRef]

2. Valdes-Abellan, J.; Pardo, M.; Jódar-Abellán, A.; Pla, C.; Fernandez-Mejuto, M. Climate change impact on karstic aquifer hydrodynamics in southern Europe semi-arid region using the KAGIS model. Sci. Total Environ. 2020, 723, 138110. [CrossRef] [PubMed]

3. Ullah, H.; Santiago-Arenas, R.; Ferdous, Z.; Attia, A.; Datta, A. Improving water use efficiency, nitrogen use efficiency, and radiation use efficiency in field crops under drought stress: A review. Adv. Agron. 2019, 156, 109-157.

4. Mansour, E.; Moustafa, E.S.; Desoky, E.M.; Ali, M.; Yasin, M.A.; Attia, A.; Alsuhaibani, N.; Tahir, M.U.; El-Hendawy, S. Multidimensional evaluation for detecting salt tolerance of bread wheat genotypes under actual saline field growing conditions. Plants 2020, 9, 1324. [CrossRef] [PubMed]

5. Attia, A.; El-Hendawy, S.; Al-Suhaibani, N.; Tahir, M.U.; Mubushar, M.; dos Santos Vianna, M.; Ullah, H.; Mansour, E.; Datta, A. Sensitivity of the DSSAT model in simulating maize yield and soil carbon dynamics in arid Mediterranean climate: Effect of soil, genotype and crop management. Field Crops Res. 2021, 260, 107981. [CrossRef]

6. Awaad, H.A.; Mansour, E.; Akrami, M.; Fath, H.E.; Javadi, A.A.; Negm, A. Availability and feasibility of water desalination as a non-conventional resource for agricultural irrigation in the mena region: A review. Sustainability 2020, 12, 7592. [CrossRef]

7. Desoky, E.M.; Mansour, E.; Yasin, M.A.; El Sobky, E.E.; Rady, M.M. Improvement of drought tolerance in five different cultivars of Vicia faba with foliar application of ascorbic acid or silicon. Span. J. Agric. Res. 2020, 18, 16. [CrossRef]

8. Mansour, E.; Desoky, E.-S.M.; Ali, M.M.; Abdul-Hamid, M.I.; Ullah, H.; Attia, A.; Datta, A. Identifying drought-tolerant genotypes of faba bean and their agro-physiological responses to different water regimes in an arid Mediterranean environment. Agric. Water Manag. 2021, 247, 106754. [CrossRef]

9. Bodner, G.; Loiskandl, W.; Kaul, H.-P. Cover crop evapotranspiration under semi-arid conditions using FAO dual crop coefficient method with water stress compensation. Agric. Water Manag. 2007, 93, 85-98. [CrossRef]

10. Jabloun, M.d.; Sahli, A. Evaluation of FAO-56 methodology for estimating reference evapotranspiration using limited climatic data: Application to Tunisia. Agric. Water Manag. 2008, 95, 707-715. [CrossRef]

11. Allen, R.G.; Pereira, L.S.; Raes, D.; Smith, M. Crop evapotranspiration-Guidelines for computing crop water requirements-FAO Irrigation and drainage paper 56. Fao Rome 1998, 300, D05109.

12. Penman, H.L. Natural evaporation from open water, bare soil and grass. Proc. R. Soc. Lond. Ser. A Math. Phys. Sci. 1948, 193, 120-145.

13. Monteith, J. Evaporation and surface temperature. Q. J. R. Meteorol. Soc. 1981, 107, 1-27. [CrossRef]

14. Tabari, H.; Talaee, P.H. Sensitivity of evapotranspiration to climatic change in different climates. Glob. Planet. Chang. 2014, 115, 16-23. [CrossRef]

15. Liu, Y.; Liu, Y.; Chen, M.; Labat, D.; Li, Y.; Bian, X.; Ding, Q. Characteristics and drivers of reference evapotranspiration in hilly regions in southern China. Water 2019, 11, 1914. [CrossRef]

16. FAOSTAT. Food and Agriculture Organization of the United Nations. Available online: http://www.fao.org/statistics/en/ (accessed on 13 March 2021).

17. Shiferaw, B.; Prasanna, B.M.; Hellin, J.; Bänziger, M. Crops that feed the world 6. Past successes and future challenges to the role played by maize in global food security. Food Secur. 2011, 3, 307-327. [CrossRef]

18. Klopfenstein, T.; Erickson, G.; Berger, L. Maize is a critically important source of food, feed, energy and forage in the USA. Field Crops Res. 2013, 153, 5-11. [CrossRef]

19. Todaka, D.; Shinozaki, K.; Yamaguchi-Shinozaki, K. Recent advances in the dissection of drought-stress regulatory networks and strategies for development of drought-tolerant transgenic rice plants. Front. Plant Sci. 2015, 6, 84. [CrossRef]

20. Pires, M.V.; de Castro, E.M.; de Freitas, B.S.M.; Lira, J.M.S.; Magalhães, P.C.; Pereira, M.P. Yield-related phenotypic traits of drought resistant maize genotypes. Environ. Exp. Bot. 2020, 171, 103962. [CrossRef]

21. Shirinbayan, S.; Khosravi, H.; Malakouti, M.J. Alleviation of drought stress in maize (Zea mays) by inoculation with Azotobacter strains isolated from semi-arid regions. Appl. Soil Ecol. 2019, 133, 138-145. [CrossRef] 
22. Mohammadi, H.; Akhondzadeh, M.; Ghorbanpour, M.; Aghaee, A. Physiological responses and secondary metabolite ingredients in sage plants induced by 24-epibrassinolide foliar application under different water deficit regimes. Sci. Hortic. 2020, 263, 109139. [CrossRef]

23. Desoky, E.M.; Mansour, E.; Ali, M.; Yasin, M.A.; AbdulHamid, M.I.; Rady, M.M.; Ali, E.F. Exogenously used 24-epibrassinolide promotes drought tolerance in maize hybrids by improving plant and water productivity in an arid environment. Plants 2021, 10, 354. [CrossRef]

24. Farajollahi, Z.; Eisvand, H.R. Storage duration and temperature of hydroprimed seeds affects some growth indices and yield of wheat. Plant Physiol. 2016, 7, 1909-1917.

25. Damalas, C.A.; Koutroubas, S.D.; Fotiadis, S. Hydro-Priming Effects on Seed Germination and Field Performance of Faba Bean in Spring Sowing. Agriculture 2019, 9, 201. [CrossRef]

26. Golbashy, M.; Ebrahimi, M.; Mostafavi, K. Effects of drought stress on germination indices of corn hybrids (Zea mays L.). Electron. J. Plant Breed. 2012, 3, 664-670.

27. Mahmoodi, T.M.; Ghassemi-Golezani, K.; Habibi, D.; Paknezhad, F.; Ardekani, M.-R. Effect of hydro-priming duration on seedling vigour and field establishment of maize (Zea mays L.). Res. Crops 2011, 12, 341-345.

28. Da Silva, C.B.; Marcos-Filho, J.; Jourdan, P.; Bennett, M.A. Performance of bell pepper seeds in response to drum priming with addition of 24-epibrassinolide. HortScience 2015, 50, 873-878. [CrossRef]

29. Kumar, M.; Pant, B.; Mondal, S.; Bose, B. Hydro and halo priming: Influenced germination responses in wheat Var-HUW-468 under heavy metal stress. Acta Physiol. Plant. 2016, 38, 1-7. [CrossRef]

30. Sime, G.; Aune, J.B. On-farm seed priming and fertilizer micro-dosing: Agronomic and economic responses of maize in semi-arid Ethiopia. Food Energy Secur. 2020, 9, e190. [CrossRef]

31. Ashraf, M.; Foolad, M.R. Pre-sowing seed treatment-A shotgun approach to improve germination, plant growth, and crop yield under saline and non-saline conditions. Adv. Agron. 2005, 88, 223-271.

32. Sliwinska, E.; Bassel, G.W.; Bewley, J.D. Germination of Arabidopsis thaliana seeds is not completed as a result of elongation of the radicle but of the adjacent transition zone and lower hypocotyl. J. Exp. Bot. 2009, 60, 3587-3594. [CrossRef]

33. Varier, A.; Vari, A.K.; Dadlani, M. The subcellular basis of seed priming. Curr. Sci. 2010, 99, 450-456.

34. Hussain, S.; Zheng, M.; Khan, F.; Khaliq, A.; Fahad, S.; Peng, S.; Huang, J.; Cui, K.; Nie, L. Benefits of rice seed priming are offset permanently by prolonged storage and the storage conditions. Sci. Rep. 2015, 5, 1-12. [CrossRef] [PubMed]

35. Gallardo, K.; Job, C.; Groot, S.P.; Puype, M.; Demol, H.; Vandekerckhove, J.; Job, D. Proteomic analysis of Arabidopsis seed germination and priming. Plant Physiol. 2001, 126, 835-848. [CrossRef] [PubMed]

36. Kibinza, S.; Bazin, J.; Bailly, C.; Farrant, J.M.; Corbineau, F.; El-Maarouf-Bouteau, H. Catalase is a key enzyme in seed recovery from ageing during priming. Plant Sci. 2011, 181, 309-315. [CrossRef] [PubMed]

37. Patane, C.; Cavallaro, V.; Avola, G.; D’Agosta, G. Seed respiration of sorghum (Sorghum bicolor (L.) Moench during germination as affected by temperature and osmoconditioning. Seed Sci. Res. 2006, 16, 251-260. [CrossRef]

38. Hussain, S.; Khan, F.; Hussain, H.A.; Nie, L. Physiological and biochemical mechanisms of seed priming-induced chilling tolerance in rice cultivars. Front. Plant Sci. 2016, 7, 116. [CrossRef] [PubMed]

39. Beckers, G.J.; Conrath, U. Priming for stress resistance: From the lab to the field. Curr. Opin. Plant Biol. 2007, 10, 425-431. [CrossRef]

40. Jisha, K.; Vijayakumari, K.; Puthur, J.T. Seed priming for abiotic stress tolerance: An overview. Acta Physiol. Plant. 2013, 35, 1381-1396. [CrossRef]

41. Afzal, I.; Basra, S.M.; Ahmad, N.; Cheema, M.A.; Warraich, E.A.; Khaliq, A. Effect of priming and growth regulator treatments on emergence and seedling growth of hybrid maize (Zea mays L.). Int. J. Agric. Biol. 2002, 4, 303-306.

42. Farooq, M.; Usman, M.; Nadeem, F.; ur Rehman, H.; Wahid, A.; Basra, S.M.; Siddique, K.H. Seed priming in field crops: Potential benefits, adoption and challenges. Crop Pasture Sci. 2019, 70, 731-771. [CrossRef]

43. Andoh, H.; Kobata, T. Effct of hardening, wetting and redrying before sowing, on germination and seedling emergence of a Japanese wheat variety Norin 61 in desiccated soil. Plant Prod. Sci. 2001, 4, 50-55. [CrossRef]

44. Mahajan, G.; Sarlach, R.; Japinder, S.; Gill, M. Seed priming effects on germination, growth and yield of dry direct-seeded rice. J. Crop Improv. 2011, 25, 409-417. [CrossRef]

45. Mansour, E.; Moustafa, E.S.; El-Naggar, N.Z.; Abdelsalam, A.; Igartua, E. Grain yield stability of high-yielding barley genotypes under Egyptian conditions for enhancing resilience to climate change. Crop Pasture Sci. 2018, 69, 681-690. [CrossRef]

46. Hatfield, J.L.; Dold, C. Water-use efficiency: Advances and challenges in a changing climate. Front. Plant Sci. 2019, 10, 103. [CrossRef]

47. Irmak, S.; Djaman, K.; Rudnick, D.R. Effect of full and limited irrigation amount and frequency on subsurface drip-irrigated maize evapotranspiration, yield, water use efficiency and yield response factors. Irrig. Sci. 2016, 34, 271-286. [CrossRef]

48. Liu, H.; Wang, X.; Zhang, X.; Zhang, L.; Li, Y.; Huang, G. Evaluation on the responses of maize (Zea mays L.) growth, yield and water use efficiency to drip irrigation water under mulch condition in the Hetao irrigation District of China. Agric. Water Manag. 2017, 179, 144-157. [CrossRef]

49. Bozkurt, S.; Yazar, A. Effects of different drip irrigation levels on yield and some agronomic characteristics of raised bed planted corn. Afr. J. Agric. Res. 2011, 6, 5291-5300. 
50. Kuscu, H.; Karasu, A.; Mehmet, O.; Demir, A.O.; Turgut, I. Effect of irrigation amounts applied with drip irrigation on maize evapotranspiration, yield, water use efficiency, and net return in a sub-humid climate. Turk. J. Field Crops 2013, 18, 13-19.

51. Kuscu, H.; Demir, A.O. Yield and water use efficiency of maize under deficit irrigation regimes in a sub-humid climate. Philipp. Agric. Sci. 2013, 96, 32-41.

52. Comas, L.H.; Trout, T.J.; DeJonge, K.C.; Zhang, H.; Gleason, S.M. Water productivity under strategic growth stage-based deficit irrigation in maize. Agric. Water Manag. 2019, 212, 433-440. [CrossRef]

53. Zhang, H.; Han, M.; Comas, L.H.; DeJonge, K.C.; Gleason, S.M.; Trout, T.J.; Ma, L. Response of maize yield components to growth stage-based deficit irrigation. Agron. J. 2019, 111, 3244-3252. [CrossRef]

54. NeSmith, D.; Ritchie, J. Effects of soil water-deficits during tassel emergence on development and yield component of maize (Zea mays). Field Crops Res. 1992, 28, 251-256. [CrossRef]

55. Bharathi, A.; Ragavan, T.; Geethalakshmi, V.; Rathinasamy, A.; Amutha, R. Influence of deficit irrigation schedules on nutrient uptake of maize hybrid under drip system. J. Pharmacogn. Phytochem. 2018, 7, 272-275.

56. Rafiee, M.; Kalhor, M. Economic water use efficiency of corn (Zea mays L.) hybrids as affected by irrigation regimes: A case study in West Iran. Arch. Agron. Soil Sci. 2016, 62, 781-789. [CrossRef]

57. Greaves, G.E.; Wang, Y.-M. Effect of regulated deficit irrigation scheduling on water use of corn in southern Taiwan tropical environment. Agric. Water Manag. 2017, 188, 115-125. [CrossRef]

58. Wang, J.; Tong, L.; Kang, S.; Li, F.; Zhang, X.; Ding, R.; Du, T.; Li, S. Flowering characteristics and yield of maize inbreds grown for hybrid seed production under deficit irrigation. Crop Sci. 2017, 57, 2238-2250. [CrossRef]

59. Siyami, R.; Mirshekari, B.; Farahvash, F.; Rashidi, V.; Tarinejad, A. The effect of physical priming of seed on traits and yield of corn (Zea mays L.) under water deficit conditions in Iran. Appl. Ecol. Environ. Res. 2018, 16, 617-627. [CrossRef]

60. Farooq, M.; Basra, S.; Khalid, M.; Tabassum, R.; Mahmood, T. Nutrient homeostasis, metabolism of reserves, and seedling vigor as affected by seed priming in coarse rice. Botany 2006, 84, 1196-1202. [CrossRef]

61. Hussain, M.; Farooq, M.; Basra, S.M.; Ahmad, N. Influence of seed priming techniques on the seedling establishment, yield and quality of hybrid sunflower. Int. J. Agric. Biol. 2006, 8, 14-18.

62. Rehman, H.U.; Basra, S.M.A.; Farooq, M. Field appraisal of seed priming to improve the growth, yield, and quality of direct seeded rice. Turk. J. Agric. For. 2011, 35, 357-365.

63. Nouman, W.; Siddiqui, M.T.; Basra, S.M.A.; Afzal, I.; Rehman, H.U. Enhancement of emergence potential and stand establishment of Moringa oleifera Lam. by seed priming. Turk. J. Agric. For. 2012, 36, 227-235.

64. Ur Rehman, H.; Iqbal, H.; Basra, S.M.; Afzal, I.; Farooq, M.; Wakeel, A.; Ning, W. Seed priming improves early seedling vigor, growth and productivity of spring maize. J. Integr. Agric. 2015, 14, 1745-1754. [CrossRef]

65. Adhikary, R.; Mandal, V. Hydro-priming and hydration-dehydration treatment improve seed invigoration and biotic stress tolerance. Russ. Agric. Sci. 2019, 45, 35-42. [CrossRef]

66. Bakht, J.; Shafi, M.; Shah, R.; Munir, I. Response of maize cultivars to various priming sources. Pak. J. Bot. 2011, 43, $205-212$.

67. Wasaya, A.; Zhang, X.; Fang, Q.; Yan, Z. Root phenotyping for drought tolerance: A review. Agronomy 2018, 8, 241. [CrossRef]

68. Kipkorir, E.; Raes, D.; Massawe, B. Seasonal water production functions and yield response factors for maize and onion in Perkerra, Kenya. Agric. Water Manag. 2002, 56, 229-240. [CrossRef]

69. Bozkurt, Y.; Yazar, A.; Gençel, B.; Sezen, M.S. Optimum lateral spacing for drip-irrigated corn in the Mediterranean Region of Turkey. Agric. Water Manag. 2006, 85, 113-120. [CrossRef]

70. Farré, I.; Faci, J.-M. Deficit irrigation in maize for reducing agricultural water use in a Mediterranean environment. Agric. Water Manag. 2009, 96, 383-394. [CrossRef] 